\title{
LX. A reply to Mr. Donovan's observations, \&C. on Mr. De Luc's paper published in our number for February
}

\section{J.A. De Luc Esq. F.R.S.}

To cite this article: J.A. De Luc Esq. F.R.S. (1815) LX. A reply to Mr. Donovan's observations, \&c. on Mr. De Luc's paper published in our number for February , Philosophical Magazine Series 1, 45:205, 329-333, DOI: $10.1080 / 14786441508638447$

To link to this article: http://dx.doi.org/10.1080/14786441508638447

电 Published online: 27 Jul 2009.

Submit your article to this journal $\pi$

Џll Article views: 2

Q View related articles $\sqsubset$ 
Fig. 9. Root common to all rich earth: the root being larger still.

Fig. X. The first sort of pump; the second sort of pump, fig. XI.

LX. A Reply to Mr. Donovan's Olservations, E̊c. on Mr. DE Luc's Paper fullished in our Number for February. By J. A. Dx Luc, Esq. F.R.S. Ëc.

\section{To $M r$. Tilloch.}

$S_{\mathbf{R},-} \mathbf{I}_{\mathbf{N}}$ your Journal for March, art. xxxvii. I find " Observations on a Paper by J. A. De Luc, Esq. containing some Renaarks on Mr. Donovan's Reflections concerning the Inadequacy of electrical Hypotheses ; by M. Donovan, Esq."

If philosophical controversies were always carried on with such a tranquillity and fairness as reigns in that between Mr. Donoväu and myself, such discussions would better forward true natural philosophy than they commonly do. I hope it will be the case when I shall have explained myself respecting what appears a disagreement between us.

A first point relates to the object of excitation. I had not present to my memory all the parts of Franklin's theory with regard to that part of electric science, when finding it in Mr. Donovan's paper, and considering it as his own opinion, I urade some objections against it; therefore he has reason to say that it does not prove against him, but against Franklin; in proof of which he quotes the Doctor's work, "Experiments and Observations on Electricity," published in London in 1749.

The most important point in our controversy concerns Volta's theory, of which I thought to give a proof by an experiment against which Mr. Donovan objects. The theory of that justly celebrated electrician is, that the standard of plus and mimus in our observations is no fixed point, but changealle, being the actual electric stute of the ambient air. My experiments to prove jt, which I still consider as decisive, Mr. Donovan accurately describes, and I shall repeat them in his own words; in which, however, he uses an expression which has misled him, and which I shall point out afterwards.

"By the continual dispersion of electicity in a room (where an electric machine was worked, having a print fixed to the prime conductor), the air of the room was rendered posiliee; a pair of insulated pith-balls in the naturd state was bo nught in from an adjoining room; they were diverged negatu'ty; but when they returned to the room whence they came, the natural state 
was resumed. Mr. De Lste explains this by supposing, that although the balls were at first in the natural state when compared with the electric state of that room; yet, when brought into an air containing a greater absolute quantity of electricity, they became relatively negative. Now if this admits a different explanation, the necessity of the above inference is destroyed; it is therefore of importance to try if this can be effected...... Now it appears to me, that the principle of electric influence may be applied in explanation of Mir. De Luc's experiments on electrified air. The balls in the natural state are brought into a positive atmosphere; the electricity of the latter repels the natural quantity of the balls into their internal substance; the external parts therefore are left minus. With this view the sequel exactly corresponds; for, when the balls were brought back into the unelectrified room, they collapsed into their natural state. But on the opposite view, the balls by immersion into a positive atmosphere would assume that state and retain it when removed, and therefore continue to diverge. Hence it appears to me, that the experiment is an anomaly on the hypothesis of Volta, and perfectly reconcileable to the principle of Franklin."

I think that some further explanations will remove Mr. Donovan's dificulties; and the most direct way will be by stating in what consists the difference between the two theories. - In Dr. Franklin's, the standard of plus and minus was a certain (supposed) natural quartity of electrity belonging to all the substances of onr globe, which fixation as mercly arbitrary, and opposed by facts, prevcited that thcory, though true in itself, from being admitted by a great number of natural philosophers both in England and on the continent; it was even by such strong arguments explained in my works, that they were never answered by retaining that theory.

But Volta's theory has produced two great and permanent changes in the science of elcctricity. IIc first proved that there is no fixed nor permanent standard of plus and minus; that the standard was changeable, being the actual electric state of ambiont air. He next explained the cause of the electric motions of pairs of balls, by proving that air possesses the electric fluid as well as all the bodies which it embraces; but with this circumstance, that it abandons some to the bodies that have less, and takes some from those which have more than itself : lastly, that as the electric fuid has some adthesion to the bodies which possess it, if these bodies oppose less resistance to move than to part with the excess, or to receive their defect, they are transported by the electric fluid where it has a tendency to move.

I have demonstrated that effect by an analogous experiment made with a pair of small soap disks suspended by thin threads, 
as a pair of pith-balls. When these disks were laid together on water they diverged, and the cause of that divergence was visille: both disks gave soap to the water between them, but only one to the external water on both sides; and the disks moving towards this, they separated from each other, or diverged.

Returning to electric motions, Volta's theory was submitted to direct verification by the experiment which $\mathrm{Mr}$, Donovan examines. But I shall first remark, that by changing the expression which I had used in explaiuing these phænomena, he has not undertood me, nor conld he understand Volta's theory. He uses the expression natural state, to define the elertric sate of the air in the room next to that in which an electric machine was set in motion; whereas I had used the expression, the actual electric slate of the air in that room, in which the pair of balls which were in the same electric state did not, nor could not diverge. If therefore $\mathrm{Mr}$. Donovan in his reasoning changes the expression natural stale, into that of actual and local electric state of the ambient air, he will find that his objection is not applicable to the explanation of the phænomena which I have observed.

Mr. Donovan makes this objection, "that the pribr of balls brought from the next room, when coming in a positive atmosphere should be rendered positive, and continue to diverge so, when brought back to the first room." This was not the case, however. Therefore Mr. Donovan's oljection is argainst a fact. But this would certainly have happened, hid that pair of balls remained long enough in the room of the electric machine; for the air communicating at least its own electric state, they would then cease to diverge; but in that case, when brought back ts the first room, instead of collapsing, they would have diverged at positive; having thus changed their electric state. Now Vulta's theory explains all these cases: it is founded on this propers: of air, that it is a non-contuctor, and cannot communicate the electric fluid to the bodies which it surrounds, or take some from them but in alsolute contact; and from this circumstance proceeds the insulation of electrified bodies in air. However, ly the continuance of the contact of the particles of air, these bodies are by degrees reduced gradually to its electric state.

With respect to electric influences, no true conclusion can bo derived from experiments on that object when the air is not $d r y$. For moisture is produced in the air by aqueous vapour, a conducting Anid; wherefore, in all my electric experiments, I had in the same room the-hygrometer of my construetion, ant I made them at times when that hygrometer stood at about the same degree, as I have stated it in my paper in Nieholson's PhiJorophieal Journal. Mr. Donovan had not this test in his exper:- 
ments with an excited glass tube, which he brought under a pith-ball, and when removing the tube, the ball remainerl positive. This effect was probably owitg to the aqueous vapour being then abundarit in the room, and thus producing a conducting medium.

Coming now to the great object of electricity, namely, the divergence of the elentrified ball, which is our electromete $\dot{r}$; Mr.D. declares with ingemonsness that he has not had opportmmity to see Volta's system compietely stated; but he says, if I understand, it relates to two hodies, one of which is in a natural state, and the otlier in a super-natural state. But this is a misconception: Volta's theory relates to two borlies, bot/l either pusitive or negative; and this divergence I have thus explained from Volta's theory, as in a pair of balls thus situated, loth act to bring the air between them to their eiectric state; while one only acts on the external air on both sides, to which therefore they tend decidedly.

Mr. Donovan objects against that explanation, "that it virtwally destroys the principle of repulsion, and refers all to attraction." This is true in the common acceptation of the words attraction and repulsion; but in strict natural philosophy, they ought to be called tendencies, as a vi ille effect, not implying the idea of cause, of which we might remain ignorant. But Mr. Donovan asks, "How can it he supposed at the same time, that electrirty is an elastic flu:d?" In Volta's theory electricity is only considered as an elastic fluid, in the upper region of the atmosphere; for, when it is produced in a manuer which I have explained, it darts in a straight line and soon vanishes, as seen in lightning. But within the atmosphere it is a parasite fluid, always fixed to the particles of air; and I have proved, by an experiment related in my work Idées sur la Météorologie, that a perfect racuum free from aquoous vapour is not a conductor. This experiment I male in presence of Dr. Franklin and some other experimental philosophers, who, knowing my opinion, desired to submit it to a test which Dr. Franklin himself preseribed. I performed the experiment, by which it was completely proved that a porfect vacuurn did not transmit the electric fluid. Thus, after having doubted, they were fully convinced of this fact, that the electric fuid is really a parasite fluid, always attached to the particles of some atmospheric fluid and moving with them.

There remains another object of disagreement between $\mathrm{Mr}$. Donovan and myself, concerning the impermeability of glass to the elertric matter, which in my works on Electicity I had maintained as the real cause of the phrnomena of the Leyden vial. On this object Mr. Donovan refers me to an interesting experiment which he has made, and thus deseribes: "A thin 
Aask of glass with a neck many inches long was half-filled with mercury, and coated on the outside to the same height with foil. By means of a movcable wire, an electric charge was thrown in ; the wire was drawn out, and the neck was hermetically sealed. After a length of time the sealing of the neck was cut off; the wire was plunged into the mercury, but not the smallest commotion was perceived by the hand; although the original charge was capable of giving a violent shock. Thus I had encompassed a quantity of electricity on all sides by glass: after a certain time I found that the glass contained none. What should I conclude, but that it escaped? Were Mr. De Luc to repeat this experiment, he would certainly consider my inference as natural."

I am too old and too infirm to undertake any new experiments; I shall therefore only suggest an idea which Mr. Donovan may easily try. Glass becomes a conductor when heated; thus it may be that the flask was discharged, by the operation of sealing it; for the operation of hermetically sealing it, requires a great heat. I therefore suspect that the moment when the flask was sealed, it was discharged. This appears to me more ratural than to suppose, against all the known phænomena of the Leyden vial, that glass is permealle to the electric matter. But Mr. Donovan might easily put it to the test of experiment in the manner above pointed out.

$$
\text { I am, sir, }
$$

Your most obedent servant,

J. A. DE Luc.

LXI. Olservations on the Priority of Mr. SMrTh's Investigations of the Strata of England; on the very unhandsome Conduct of certain Persons in detracting from his Merit therein; and the Endeavours of others to supplant him in the Sale of his Maps;-with a Reply to Mr.W. H. Gilby's Letter in the last Number. By Mir. JoIn Farex, Sen.

\section{To Mr. Tilloch.}

SiR, $-T_{H E}$ rash and unfounded reflections, which a Mr. IV. H. Gllby has been induced to address to you from Edinburgh, pages 300 and 301 of your last Number, would not at this time have occasioned ne to trouble you thereon, but for the very superior calls of justice as well as friendship, in favour of $\mathrm{Mr}$. IVilliam Smilh's irresistible claim to the discovery of the order, and to priority in the actual tracing and mapping of the surfaces of the principal part of the British series of Strata, and those scarcely less urgent calls, to support the cause of practical Eng- 